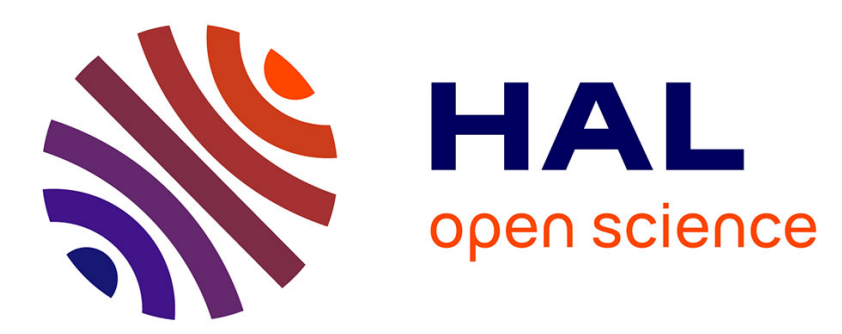

\title{
Waterlogging under simulated late-winter conditions had little impact on the physiology and growth of Norway spruce seedlings
}

\author{
Ai-Fang Wang, Marja Roitto, Tarja Lehto, Janusz Zwiazek, Mónica \\ Calvo-Polanco, Tapani Repo
}

\section{To cite this version:}

Ai-Fang Wang, Marja Roitto, Tarja Lehto, Janusz Zwiazek, Mónica Calvo-Polanco, et al.. Waterlogging under simulated late-winter conditions had little impact on the physiology and growth of Norway spruce seedlings. Annals of Forest Science, 2013, 70 (8), pp.781-790. 10.1007/s13595-013-0325-5 . hal-01201524

\section{HAL Id: hal-01201524 \\ https://hal.science/hal-01201524}

Submitted on 17 Sep 2015

HAL is a multi-disciplinary open access archive for the deposit and dissemination of scientific research documents, whether they are published or not. The documents may come from teaching and research institutions in France or abroad, or from public or private research centers.
L'archive ouverte pluridisciplinaire HAL, est destinée au dépôt et à la diffusion de documents scientifiques de niveau recherche, publiés ou non, émanant des établissements d'enseignement et de recherche français ou étrangers, des laboratoires publics ou privés. 


\title{
Waterlogging under simulated late-winter conditions had little impact on the physiology and growth of Norway spruce seedlings
}

\author{
Ai-Fang Wang • Marja Roitto • Tarja Lehto • \\ Janusz J Zwiazek • Mónica Calvo-Polanco • Tapani Repo
}

Received: 8 May 2013 / Accepted: 18 August 2013/Published online: 6 September 2013

(C) INRA and Springer-Verlag France 2013

\begin{abstract}
- Context Waterlogging is predicted to become more common in boreal forests during winter and early spring with climate change. So far, little is known about the waterlogging tolerance of boreal tree species during their winter dormancy. - Aim The aim was to quantify the degree of waterlogging tolerance of 1-year-old dormant Norway spruce (Picea abies (L.) Karst.) seedlings.

- Methods The seedlings were exposed to waterlogging in a growth chamber at temperature of $2{ }^{\circ} \mathrm{C}$ for 4 weeks and then allowed to recover for 6 weeks during the growth stage. Shoot and root responses were monitored by physiological and growth measurements.

- Results No effect was found in the seedling biomass, but root mortality increased slightly during the early growth stage following waterlogging. The water potential of the needles
\end{abstract}

\section{Handling Editor: Erwin Dreyer}

Contribution of the co-authors Wang, Roitto, Lehto and Repo designed the experiment. Wang was responsible for running the experiment, analysis of the results, and majority of the writing. All the authors have contributed in preparing of the manuscript.

A.-F. Wang $\cdot$ M. Roitto $\cdot$ T. Repo $(\bowtie)$

The Finnish Forest Research Institute, Joensuu, P.O. Box 68,

FI-80101 Joensuu, Finland

e-mail: tapani.repo@metla.fi

A.-F. Wang $\cdot$ T. Lehto

School of Forest Sciences, University of Eastern Finland,

P.O. Box 111, FI-80101 Joensuu, Finland

\section{J. J. Zwiazek}

Department of Renewable Resources, University of Alberta, 442

Earth Sciences Bldg., Edmonton AB T6G 2E3, Canada

M. Calvo-Polanco

Department of Soil Microbiology and Symbiotic Systems, Estación

Experimental del Zaidín (CSIC), Granada 18008, Spain became less negative at the end of the waterlogging and the early growth stage. The ratio of apoplastic to symplastic electrical resistance $\left(R_{\mathrm{e}} / R_{\mathrm{i}}\right)$ of the needles was lower after waterlogging, indicating changes in the proportions of symplastic and apoplastic space. No differences were found between the treatments in the dark-acclimated chlorophyll fluorescence $\left(F_{\mathrm{v}} / F_{\mathrm{m}}\right)$ of the needles. Slightly greater accumulation of starch and temporary reductions of some mineral nutrients in needles were found after waterlogging.

- Conclusions We conclude that in late winter and early spring, Norway spruce seedlings potentially tolerate short periods of waterlogging.

Keywords Climate change · Dormancy · Waterlogging · Hypoxia $\cdot$ Root

\section{Introduction}

Waterlogging tolerance of the roots is an important stress resistance feature for trees, especially those growing in wetlands. In Finland, one third of the land area used to be peatland, about one half of which has been drained by ditching (Kortelainen and Saukkonen 1995). Trees growing on drained peatlands maintain a low water table for their root systems by means of transpiration and canopy interception (Sarkkola et al. 2012). In the future, however, rainfall and snowmelt frequency are predicted to increase and snowfall to decrease in northern regions during winter (Bardossy and Caspary 1990; Crawford and Braendle 1996; Jylhä et al. 2009). This is expected to elevate the water table in lowland areas and to increase risks of waterlogging in northern Europe during winter and spring (IPCC 2007).

Waterlogging is an environmental stress characterised by transient or permanent saturation of soil pores with water. It 
affects plant growth and survival by reducing $\mathrm{O}_{2}$ availability and changing the $\mathrm{pH}$ of the soil (Parent et al. 2008). Plants tend to have a wide range of mechanisms to cope with short periods of soil hypoxia in the growing season (Crawford 2003). When roots are exposed to an oxygen deficiency, their metabolic responses switch from aerobic respiration to fermentation (Kreuzwieser et al. 2004). In order to promote the uptake and transport of oxygen from the air to the roots in flooded soil, morphological adaptations, such as the formation of aerenchyma cells and hypertrophied lenticels in Scots pine (Pinus sylvestris) (Armstrong and Read 1972; Aronen and Häggman 1994) as well as of adventitious roots in tamarack (Larix laricina) (Calvo-Polanco et al. 2012), may also occur. Little attention has been paid to understanding the consequences of waterlogging during dormancy. The flooding resistance mechanisms of dormant trees are likely to be different from those of metabolically active and growing trees (Crawford 2003). For example, Sitka spruce (Picea sitchensis) seedlings suffered less root dieback when waterlogged after the cessation of root growth in November compared with 1 month earlier when they were still growing (Coutts and Nicoll 1990). Similarly, Norway spruce seedlings were found in a field experiment to tolerate high ground water levels occurring in winter and spring, i.e., before the onset of root growth, with only a slight decrease in shoot growth during the subsequent growth period (Pelkonen 1975; 1979). Soaking and consequent oxygen deficiency of roots in jack pine (Pinus banksiana Lamb.) and black spruce (Picea mariana (Mill.)) prior to outplanting were suggested to be restricted to a maximum of $8 \mathrm{~h}$ in order to avoid growth losses during the subsequent growing season (Racey 1984). However, the processes contributing to the apparently greater waterlogging tolerance of dormant seedlings are largely unknown.

Norway spruce is regarded as a flood-intolerant tree species based on field observations (Glenz et al. 2006). Therefore, the predicted increase in precipitation in winter and spring, which are likely to create temporary waterlogging conditions, may be detrimental to this species. Here, the aim was to study waterlogging tolerance of 1-year-old dormant Norway spruce seedlings. The seedlings were exposed to waterlogging for 4 weeks followed by 6 weeks of growth in drained soil in a growth chamber. Different physiological and growth attributes were monitored to gain a comprehensive view of shoot and root responses. Needle water potential, root hydraulic conductivity $\left(L_{\mathrm{p}}\right)$ and needle mineral nutrients were measured to assess if waterlogging would affect root functioning detrimentally. Accumulation of carbohydrates in needles plus the total biomass and the biomass by cohorts were measured to evaluate the growth. Chlorophyll fluorescence and electrical impedance spectroscopy (EIS) have been shown to indicate sensitively cellular responses to various stresses (Lichtenthaler and Rinderle 1988; Zhang et al. 1993; Repo et al. 1994, 2000;
Ryyppö et al. 1998; Baker 2008). Therefore, we assumed that the methods would indicate needle responses to waterlogging stress. We hypothesised that the root functioning of dormant seedlings would decline by waterlogging and this would be manifested in altered shoot physiology and reduced growth in the subsequent growth season.

\section{Materials and methods}

\subsection{Plant cultivation and waterlogging treatment}

We used 1-year-old Norway spruce (Picea abies L.) seedlings (Plantek-81F, pot volume $85 \mathrm{~cm}^{3}$, height $18-24 \mathrm{~cm}$ ) originated in Suonenjoki (Eastern Finland, 62 $2^{\circ} 39^{\prime} \mathrm{N}, 27^{\circ} 03^{\prime} \mathrm{E}$, $130 \mathrm{~m}$ a.s.1.). The growth medium was peat. Prior to the experiment, the seedlings had been stored at $-2{ }^{\circ} \mathrm{C}$ in the FinForelia forest tree nursery (Tuusjärvi, Eastern Finland, $62^{\circ} 50^{\prime} \mathrm{N}, 28^{\circ} 32^{\prime} \mathrm{E}$ ) for 7 months and then moved into a dark cold room at $+2{ }^{\circ} \mathrm{C}$ in Joensuu $\left(62^{\circ} 36^{\prime} \mathrm{N}, 29^{\circ} 45^{\prime} \mathrm{E}\right.$, $80 \mathrm{~m}$ a.s.l.) for 1 month. At the start of the experiment, the seedlings were in the second phase of dormancy, i.e., quiescence, where growth can resume whenever conditions become favourable. The seedlings were replanted, with the peat plugs intact, into black plastic pots $(7 \mathrm{~cm} \times 7 \mathrm{~cm} \times 6 \mathrm{~cm})$ with quartz sand (particle size $0.5-1.5 \mathrm{~mm}$, Nilsiä Quartz, SP. Mineral, Finland) as the culture medium. A piece of cloth was placed at the bottom of each pot to keep the sand in the pots.

Immediately after replanting, 128 seedlings were moved into a growth chamber (PGW36, Conviron, Winnipeg, Canada). They were distributed into eight containers (dimensions $33 \mathrm{~cm} \times 33 \mathrm{~cm} \times 13 \mathrm{~cm}, 16$ seedlings/container) and four replicate containers $(n=4)$ for the two treatments designed. The containers were placed in the growth chamber in a randomised order. The treatments were: (1) No waterlogging in the dormancy phase (NW) and (2) waterlogging in the dormancy phase (W). The W treatment stopped at the end of the dormancy phase. The dormancy phase lasted for 1 month, during which the air temperature was kept constant at $2{ }^{\circ} \mathrm{C}$, relative humidity at $90 \%$, photoperiod at $6 / 18 \mathrm{~h}$ (day/night) and photosynthetically active radiation (PAR) at $200 \mu \mathrm{mol} \mathrm{m} \mathrm{s}^{-2}$. The growth phase lasted for 6 weeks, during which the air temperature was $22 / 15^{\circ} \mathrm{C}$ (day/ night), relative humidity $70 / 80 \%$ (day/night), photoperiod $18 / 6 \mathrm{~h}$ (day/night) and PAR $400 \mu \mathrm{mol} \mathrm{m} \mathrm{m}^{-2} \mathrm{~s}^{-1}$. The changes in the photoperiod, light irradiance, temperature and air humidity upon the switch from dormancy to growth were made gradually during the first week of the growth phase. The change from day to night conditions was made gradually in $2 \mathrm{~h}$.

The chemical composition of the waterlogging and irrigation water (Table 1) was adjusted to match the precipitation in southern Finland (Sallantaus 1992). The non-waterlogged seedlings were irrigated twice during the dormancy phase. In 
Table 1 Chemical composition of the irrigation water

\begin{tabular}{ll}
\hline Ion & Concentration $\left(\mu \mathrm{mol} \mathrm{L}{ }^{-1}\right)$ \\
\hline $\mathrm{K}^{+}$ & 21.6 \\
$\mathrm{Ca}^{2+}$ & 31.6 \\
$\mathrm{Mg}^{2+}$ & 22.4 \\
$\mathrm{NH}_{4}^{+}$ & 280.3 \\
$\mathrm{Na}^{+}$ & 68.7 \\
$\mathrm{H}^{+}$ & 234.0 \\
$\mathrm{SO}_{4}{ }^{2-}$ & 180.0 \\
$\mathrm{Cl}^{-}$ & 134.8 \\
$\mathrm{NO}_{3}{ }^{-}$ & 214.2 \\
$\mathrm{H}_{2} \mathrm{PO}_{4}^{-}$ & 3.6 \\
\hline
\end{tabular}

the waterlogging treatment, the water table in the pots was maintained at the soil surface. After waterlogging, all the seedlings were irrigated twice a week during the growth phase. For the physiological and biomass measurements, harvests were carried out at the end of the waterlogging and the dormancy phase (H0) and after 14 days (H14), 28 days (H28) and 42 days (H42) of the growth phase. Physiological measurements had also been carried out once before the start of the waterlogging treatment. There was no initial difference in soil moisture between the two treatments before waterlogging.

The soil oxygen and the volumetric water content were monitored in eight randomly selected pots (one pot/container) before the end of the waterlogging and then three times at 2week intervals during the growth phase. The oxygen content was measured and corrected for the soil temperature by means of 4-Channel Fiber-Optic Oxygen Meter (OXY-4, PreSens, Germany). An optical sensor (Oxygen Dipping Probe, DPPSt3-L2.5-St10-Yop, PreSens, Regensburg, Germany) was inserted into the soil at a depth of $3 \mathrm{~cm}$ and the air saturated value was recorded after $10 \mathrm{~min}$. For verifying the results of the oxygen measurements, a separate set of 16 seedlings were used for soil oxygen monitoring with 16 optical sensors. The seedlings were subjected to similar waterlogging treatments (W and NW) as in the main experiment. In half of the seedlings of both groups, the oxygen sensors were placed in soil continuously, whereas in another half the sensors were set into the soil temporarily for taking the readings $10 \mathrm{~min}$ after insertion of the sensor. The soil water content was measured by means of Moisture Meter HH2 (Delta-T Devices, Cambridge, England).

\subsection{Physiology}

Eight seedlings per treatment (two seedlings per container) were sampled from each harvest for the dark-acclimated (20 min) chlorophyll fluorescence $\left(F_{\mathrm{v}} / F_{\mathrm{m}}\right)$, water potential and EIS of the previous-year needles and for root hydraulic conductance at room temperature. The harvests were destructive, i.e., different seedlings were sampled in each harvest.
Mean value of two seedlings in each container was used for statistical analyses (the number of replicated containers was four).

Five previous-year needles were picked from each seedling for the $F_{\mathrm{v}} / F_{\mathrm{m}}$ measurements. The needles were attached to a tape side by side and measured at room temperature with a portable chlorophyll fluorescence meter (MINI-PAM, Heinz Walz Gmbh, Effeltrich, Germany).

Water potential measurements took place in the morning a couple hours after the lights were switched on in the growth chamber. Three previous-year needles from each seedling were sampled, a thin slice was cut at the surface of the bottom end and pressurized by means of a pressure chamber (Scholander et al. 1964). The pressure value were recorded when the first drop of water came out from the bottom end of the needle.

The EIS was measured for three previous-year needles from each seedling (Repo et al. 1994; 2000). The method provides information about the physicochemical properties of cellular structures. It is based on passage of electric current of different frequencies through the cellular compartments. Low-frequency current may pass apoplastic space. By increasing the frequency, more current will pass cell membranes, and at high-enough frequencies, both apoplastic and symplastic space pass current concurrently. One 8 -mm-long section was cut out of the middle of the needle and set between the electrode pastes (Signagel, Parker Laboratories, Fairfield, $\mathrm{NJ}$, USA) connected by $\mathrm{Ag} / \mathrm{AgCl}$ electrodes (RC1, WPI, Ltd., Sarasota, W, USA) to the circuit analyser (HP 4284A, Agilent, Palo Alto, CA, USA). The real and the imaginary impedance values were measured at 46 frequencies between $20 \mathrm{~Hz}$ and $1 \mathrm{MHz}$. The extracellular $\left(R_{\mathrm{e}}\right)$ and the intracellular resistance $\left(R_{\mathrm{i}}\right)$ were estimated on the basis of the parameters of the distributed circuit model (single-DCE) (Repo et al. $1994)$ and the ratio $R_{\mathrm{e}} / R_{\mathrm{i}}$ was calculated.

The root hydraulic conductance $\left(K_{\mathrm{r}}\right)$ was measured with a high-pressure flow meter (HPFM, Dynamax Inc., Houston, TX, USA). The shoot was cut at about $15 \mathrm{~mm}$ above the root collar, and the HPFM device was connected to the root system at the stem above the root collar by means of a coupling set. The measurements were carried out by increasing the pressure from 0 to $0.55 \mathrm{MPa}$ (Tyree et al. 1995). The root hydraulic conductivity $\left(L_{\mathrm{p}}\right)$ was obtained by dividing the root conductance by the live root surface area.

Eight seedlings (one per container) were used to determine the soluble sugar and starch content of their needles with the method described by Hansen and Møller (1975). The needles were dried at $40{ }^{\circ} \mathrm{C}$ to a constant weight and then ground into a powder. The soluble sugars were extracted using $80 \%$ aqueous ethanol. The concentration of total soluble sugars was determined colorimetrically at $630 \mathrm{~nm}$ after reaction with anthrone. The starch was extracted from the residue using $35 \%$ perchloric acid. The starch content was determined colorimetrically at $625 \mathrm{~nm}$ with anthrone and using starch in $30 \%$ 
perchloric acid as a standard. The contents are given as percentage of dry mass of the needles. Anthrone method is commonly used in sugar analyses. The accuracy of the method is affected by occurrence of sugar mixtures. In addition, strong acid may break down structural carbohydrates to glucose leading to some overestimate of starch content (Chow and Landhäusser 2004), but in our case the bias is similar for all samples.

\subsection{Biomass}

The same seedlings as those used for the shoot physiological and root hydraulic conductance measurements (three seedlings per container) from each harvest were used for root and shoot biomass, root volume and the percentage of dead roots calculations. The dry mass of the previous- and currentyear (last two harvests) shoots was assessed after drying at $40{ }^{\circ} \mathrm{C}$ to a constant weight. The roots were carefully removed from soil and washed in tap water. Dead roots were separated from live ones by naked eye and at stereo microscopic assessment of cross sections. The live roots were scanned (STD4800 scanner, Régent Instruments Inc., Sainte-Foy, Canada), and the root volume, root length, root surface area and number of root tips were assessed using the WinRHIZO program (WinRhizo, Régent Instruments Inc., Sainte-Foy, Canada). Both dead and live roots were dried at $40{ }^{\circ} \mathrm{C}$ and weighed.

\subsection{Nutrients}

For $\mathrm{N}$ analyses (LECO CHN-1000 elemental analyser, LECO Corporation, St. Joseph, MI, USA), previous-year and current-year needles of all seedlings from each harvest (three seedlings per container) were used. After an $\mathrm{HNO}_{3}-\mathrm{H}_{2} \mathrm{O}_{2}$ digestion of the needles, extracts were analysed with an inductively coupled plasma atomic emission spectrophotometer (ICP/AES) (TJA Iris Advantage, Thermo Jarrell Ash Corporation, Franklin, MA, USA) for phosphorus (P), potassium $(\mathrm{K})$, calcium $(\mathrm{Ca})$, magnesium $(\mathrm{Mg})$, iron $(\mathrm{Fe})$, boron $(\mathrm{B})$, copper $(\mathrm{Cu})$, manganese $(\mathrm{Mn})$ and zinc $(\mathrm{Zn})$ concentrations and expressed on the dry mass basis.

\subsection{Statistical analyses}

The effects of the treatments on all the variables were analysed by means of a mixed linear model (procedure MIXED in SPSS 15.0.1, SPSS Inc., Chicago, IL). The model used was $y=\mu+$ treatment + time + treatment $\times$ time $+\varepsilon$, where $\mu$ is a constant. The 'treatment' (i.e., NW and W) and 'time' (i.e., harvest time) were regarded as fixed factors and $\varepsilon$ as a random term. The significance of the difference between the treatments at different sampling times was tested by contrasts using Bonferroni-corrected significance levels. Normality and homogeneity of the variance of the residuals were checked. The selection of the covariance structure was based on Akaine's information criteria. Response variables were logtransformed when needed to fulfill the assumptions of the analyses. The mean value of the seedlings in one container was used in the statistical analyses of the variables. The number of replicate containers was four.

\section{Results}

\subsection{Soil environment}

In the measurements done during the treatment period the air saturated soil oxygen content in NW treatment was $94 \pm 2 \%$ (Table 2). In W treatment, the mean was $64 \%( \pm 2 \%) 10$ min after insertion of the oxygen sensor in soil. However, the additional measurements with the separate set of plants showed that after $60 \mathrm{~min}$, the oxygen content was $0 \%$. The results showed that a longer stabilisation time is needed in $\mathrm{W}$ than NW due to an oxygen imbalance at the soil-sensorinterface after insertion of the sensor in soil. The differences in the oxygen contents between the treatments disappeared at the beginning of the growth phase after removal of the waterlogging condition.

The soil moisture was higher in $\mathrm{W}$ than in NW $(P<0.05)$ at the end of the dormancy phase but no differences were found between the treatments in the growth period. When the lights were on in the chamber the soil temperature was about $5{ }^{\circ} \mathrm{C}$ during the dormancy phase and $23{ }^{\circ} \mathrm{C}$ during the growth phase (Table 2).

\subsection{Physiology}

Judged by the visual appearance of the shoots, all seedlings remained healthy throughout the experiment. The effect of the

Table 2 The mean $( \pm \mathrm{SD})$ soil conditions without waterlogging (NW) and with waterlogging (W) of Norway spruce seedlings for 4 weeks during the dormancy phase. W treatment during the 'Growth' phase refers to the seedlings that were exposed to waterlogging during the 'Dormancy' phase only. The values in the 'Growth' phase are the means taken at three last harvests (14, 28 and 42 days since start of growth phase)

\begin{tabular}{lllll}
\hline Phase & Treatment & $\begin{array}{l}\text { Oxygen content, } \\
\text { \% air saturation }\end{array}$ & $\begin{array}{l}\text { Vol. water } \\
\text { content, } \%\end{array}$ & $\begin{array}{l}\text { Temperature, } \\
{ }^{\circ} \mathrm{C}\end{array}$ \\
\hline Dormancy & $\mathrm{NW}$ & $94 \pm 2$ & $57 \pm 5$ & $5.2 \pm 0.1$ \\
& $\mathrm{~W}$ & $0^{\mathrm{a}}$ & $86 \pm 6$ & $4.8 \pm 0.1$ \\
\multirow{5}{*}{ Growth } & $\mathrm{NW}$ & $92 \pm 2$ & $33 \pm 10$ & $23.1 \pm 0.7$ \\
& $\mathrm{~W}$ & $91 \pm 2$ & $34 \pm 11$ & $23.2 \pm 0.4$ \\
\hline
\end{tabular}

${ }^{\text {a }}$ Based on the oxygen monitoring with the sensors continuously in soil. Other oxygen readings were taken $10 \mathrm{~min}$ after insertion of the sensor in soil 
sampling time on the $F_{\mathrm{v}} / F_{\mathrm{m}}$ of the previous-year needles was significant $(P<0.001)$, but there were no significant differences between the treatments and the time $\times$ treatment interaction (Fig. 1a). After 14 days from the end of the dormancy phase and the waterlogging treatment (H14), the $F_{\mathrm{v}} / F_{\mathrm{m}}$ reached its maximum at 0.84 . Thereafter, the values declined gradually to the same level $(0.79)$ as they had at the end of the 30-day dormancy and waterlogging phase.

The water potential of the previous-year needles was significantly higher in $\mathrm{W}$ than in NW at the end of the dormancy phase and during the early growth phase (H14) $(P<0.05)$ (Fig. 1b), but it decreased in both treatments until H28 (28 days of growth) $(P<0.01)$.

Symplastic resistance $\left(R_{\mathrm{i}}\right)$ was slightly higher and apoplastic resistance $\left(R_{\mathrm{e}}\right)$ slightly lower in W than in NW needles, resulting in a lower $R_{\mathrm{e}} / R_{\mathrm{i}}$ ratio for the previous-year needle $(P<0.05)$ during the growth phase. The $R_{\mathrm{e}} / R_{\mathrm{i}}$ ratio decreased with time $(P<0.001)$ until harvest H28 (Fig. 1c). The time $\times$ treatment interaction was not significant.

No significant differences were found in total root hydraulic conductance $\left(K_{r}\right)$ (data not shown) or root hydraulic conductivity $\left(L_{\mathrm{p}}\right)$ (Fig. 1d) between the W and the NW treatment at any harvest time or in the time $\times$ treatment interaction. The effect of the sampling time was not significant either.

The soluble sugar content of the previous-year needles tended to be higher in $\mathrm{W}$ than in NW $(P=0.053)$, but the change over time was not significant (Fig. 1e). The starch content of the previous-year needles increased during the growth phase $(P<0.001)$, except at $\mathrm{H} 28$ (Fig. 1f), and tended to be higher in $\mathrm{W}$ than in NW, especially at $\mathrm{H} 14(P=0.062)$. The time $\times$ treatment interaction was not significant.

\subsection{Biomass}

The elongation of the needles and stems started between $\mathrm{H} 14$ and $\mathrm{H} 28$ resulting a higher total biomass at $\mathrm{H} 28$ and $\mathrm{H} 42$ than at previous harvests $(P<0.001)$. There were no differences at any of the harvest times between NW and $\mathrm{W}$ in the total biomass or of the different cohorts, i.e., previous-year and current-year needles or previous-year and current-year stems and roots (Fig. 2).

The root volume increased since H14 $(P<0.001)$. It was smaller in $\mathrm{W}$ than in NW $(P<0.05)$, except at $\mathrm{H} 28$ (Fig. 3). The effect of the time $\times$ treatment interaction was
Fig. 1 a Dark-acclimated chlorophyll fluorescence $\left(F_{\mathrm{v}} / F_{\mathrm{m}}\right)$, b water potential, $\mathbf{c}$ ratio of extracellular to intracellular electrical resistance, e soluble sugar and $\mathbf{f}$ starch content (on dry mass basis) of previous-year needles of, and $\mathbf{d}$ root hydraulic conductivity of Norway spruce seedlings by harvest time. $N W$ no waterlogging; $W$ waterlogging; $B W$ before waterlogging; $H O$ after 30 days of winter waterlogging; $\mathrm{H} 14$ after 14 days of growth; $\mathrm{H} 28$ after 28 days of growth; and $H 42$ after 42 days of growth. $P$ values are indicated when the effect of harvest time and treatment was significant, and by asterisks the difference in pairwise comparison by harvest times $(P<0.05)$. The vertical bars indicate standard errors $(n=4)$
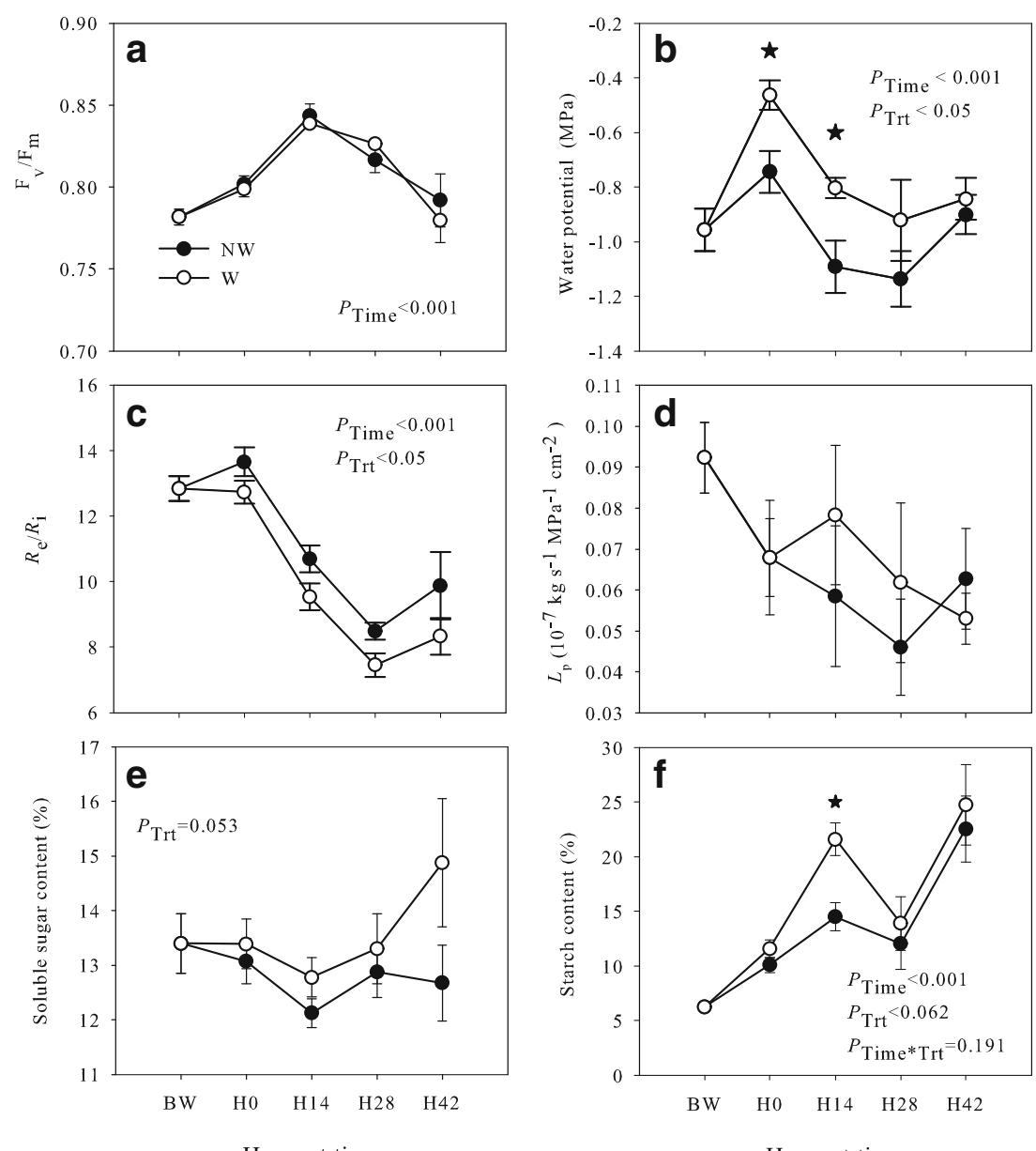

Harvest time

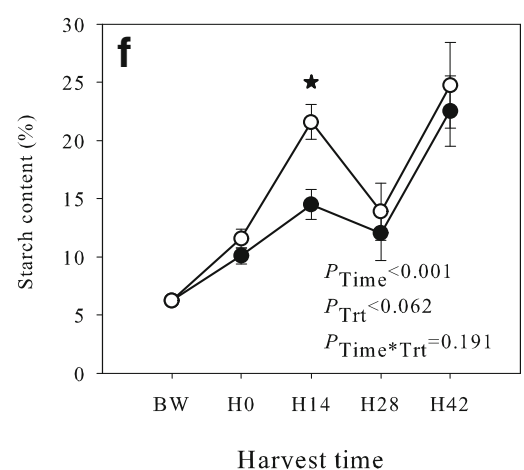




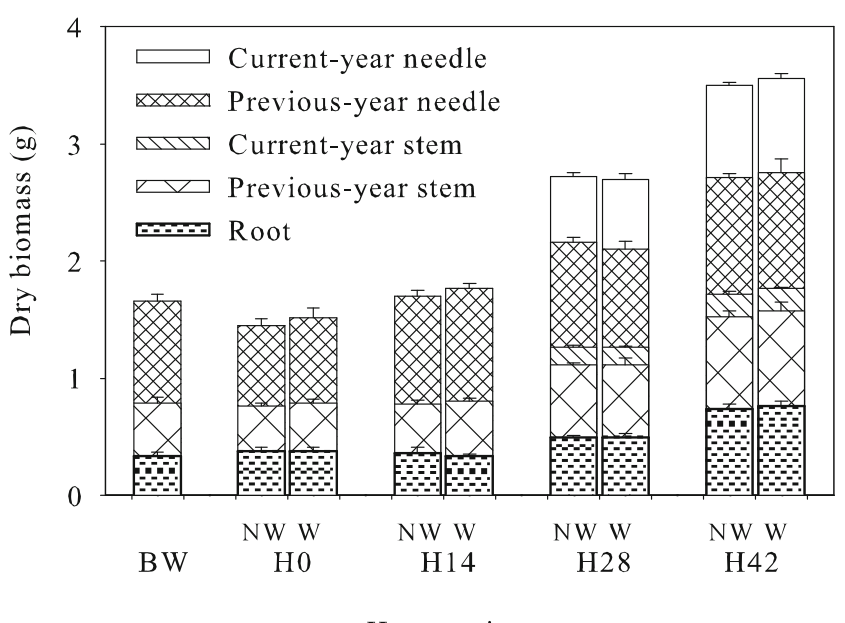

Harvest time

Fig. 2 Dry biomass of each cohort of Norway spruce seedlings by harvest times. $N W$ no waterlogging; $W$ waterlogging; $B W$ before waterlogging; $H 0$ after 30 days of winter waterlogging; $H 14$ after 14 days of growth; $\mathrm{H} 28$ after 28 days of growth; and $H 42$ after 42 days of growth. The vertical bars indicate standard errors $(n=4)$

not significant. There were no differences between the treatments in root length, root surface area, or number of root tips (data not shown).

The percentage of dead root biomass increased towards the end of the waterlogging phase ( $\mathrm{H} 0)$ and still at the beginning of the growth phase in $\mathrm{W}(\mathrm{H} 14)$ but decreased towards the end of the growth period (Fig. 4). The differences between the treatments or the time $\times$ treatment interaction were not significant due to large variability (Fig. 4).

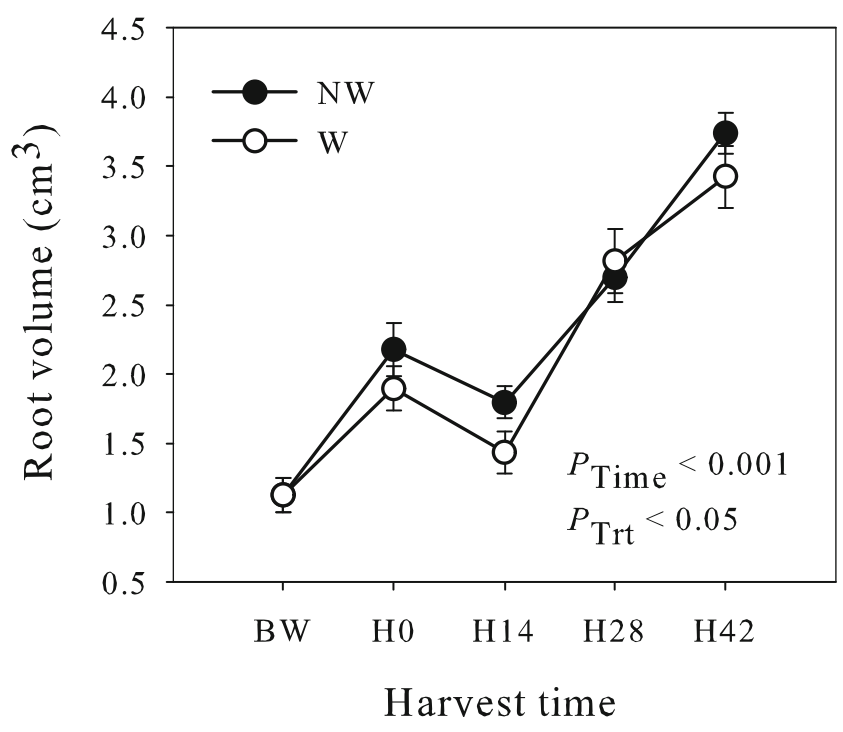

Fig. 3 Root volume of Norway spruce seedlings by harvest time. $N W$ no waterlogging; $W$ waterlogging; $B W$ before waterlogging; $H O$ after 30 days of winter waterlogging; $H 14$ after 14 days of growth; $H 28$ after 28 days of growth; and $H 42$ after 42 days of growth. $P$ values are indicated for the significant effect of harvest time and treatment. The vertical bars indicate standard errors $(n=4)$

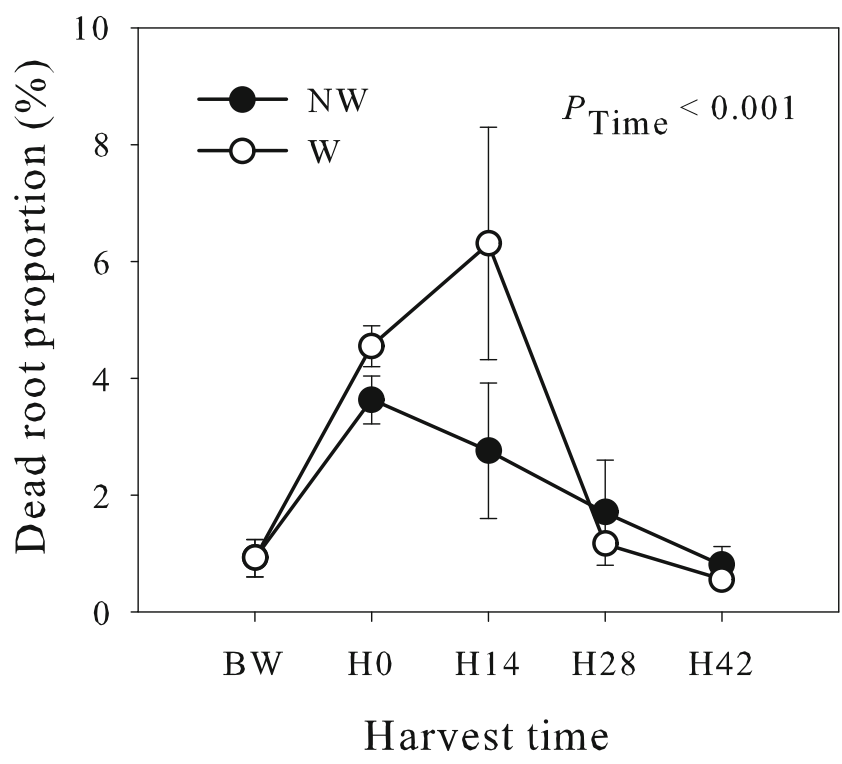

Fig. 4 Dead root proportion (out of total dry root biomass) of Norway spruce seedlings by harvest time. $N W$ no waterlogging; $W$ waterlogging; $\mathrm{BW}$ before waterlogging; $\mathrm{HO}$ after 30 days of winter waterlogging; $\mathrm{H} 14$ after 14 days of growth; $H 28$ after 28 days of growth; and $H 42$ after 42 days of growth. $P$ value is indicated for the significant effect. The vertical bars indicate standard errors $(n=4)$

\subsection{Nutrients}

The N, K, Ca, Mn, and Zn content of the previous-year needles was significantly higher in NW than in $\mathrm{W}$ at the end of the waterlogging phase (H0) $(P<0.05)$ (Fig. 5). No differences between the treatments were found during the growth phase for $\mathrm{N}, \mathrm{K}, \mathrm{Mg}, \mathrm{Mn}$, and $\mathrm{Zn}$, except for the Ca content, which was higher in NW than in $\mathrm{W}$ at the end of the experiment $(P<0.05)$. In the contents of $\mathrm{P}, \mathrm{Fe}, \mathrm{B}$, and $\mathrm{Cu}$, no differences were found between the treatments. The time effect was significant for each nutrient, except Fe.

In current-year needles, no differences were found between the treatments or the time $\times$ treatment interaction for any of the nutrients. The contents of $\mathrm{N}, \mathrm{P}, \mathrm{K}, \mathrm{Cu}$ and $\mathrm{Zn}$ were higher but the contents of $\mathrm{Ca}, \mathrm{Fe}, \mathrm{B}, \mathrm{Mn}$, and $\mathrm{Mg}$ were lower in the current than in the previous-year needles at the same harvest time. The contents of $\mathrm{N}, \mathrm{P}, \mathrm{K}, \mathrm{Cu}$, and $\mathrm{Zn}$ decreased with the progress of the growth phase $(P<0.05)$.

\section{Discussion}

Our hypothesis that the waterlogging at low temperature and consequent hypoxia of roots in dormant Norway spruce seedlings would affect the physiology and growth in the subsequent growth season without waterlogging was partly supported. Low oxygen demand may partly mitigate the harmful effects of winter flooding on dormant plants (Crawford 2003). Root respiration of waterlogged conifers, and soil oxygen use 
Fig. 5 Nitrogen (a), phosphorus (b), potassium (c), calcium (d), magnesium (e) and iron (f), boron (g), copper (h), manganese (i), and zinc (j) content of previous-year needles and current-year needles of Norway spruce seedlings by harvest time. $N W$ no waterlogging; $W$ waterlogging; $B W$ before waterlogging; $\mathrm{HO}$ after 30 days of winter waterlogging; $H 14$ after 14 days of growth; $H 28$ after 28 days of growth; and $H 42$ after 42 days of growth. $P$ values are indicated when the effect of harvest time, treatment or their interaction was significant, and asterisks the difference in pairwise comparison by harvest times $(P<0.05)$. The vertical bars indicate standard errors $(n=4)$
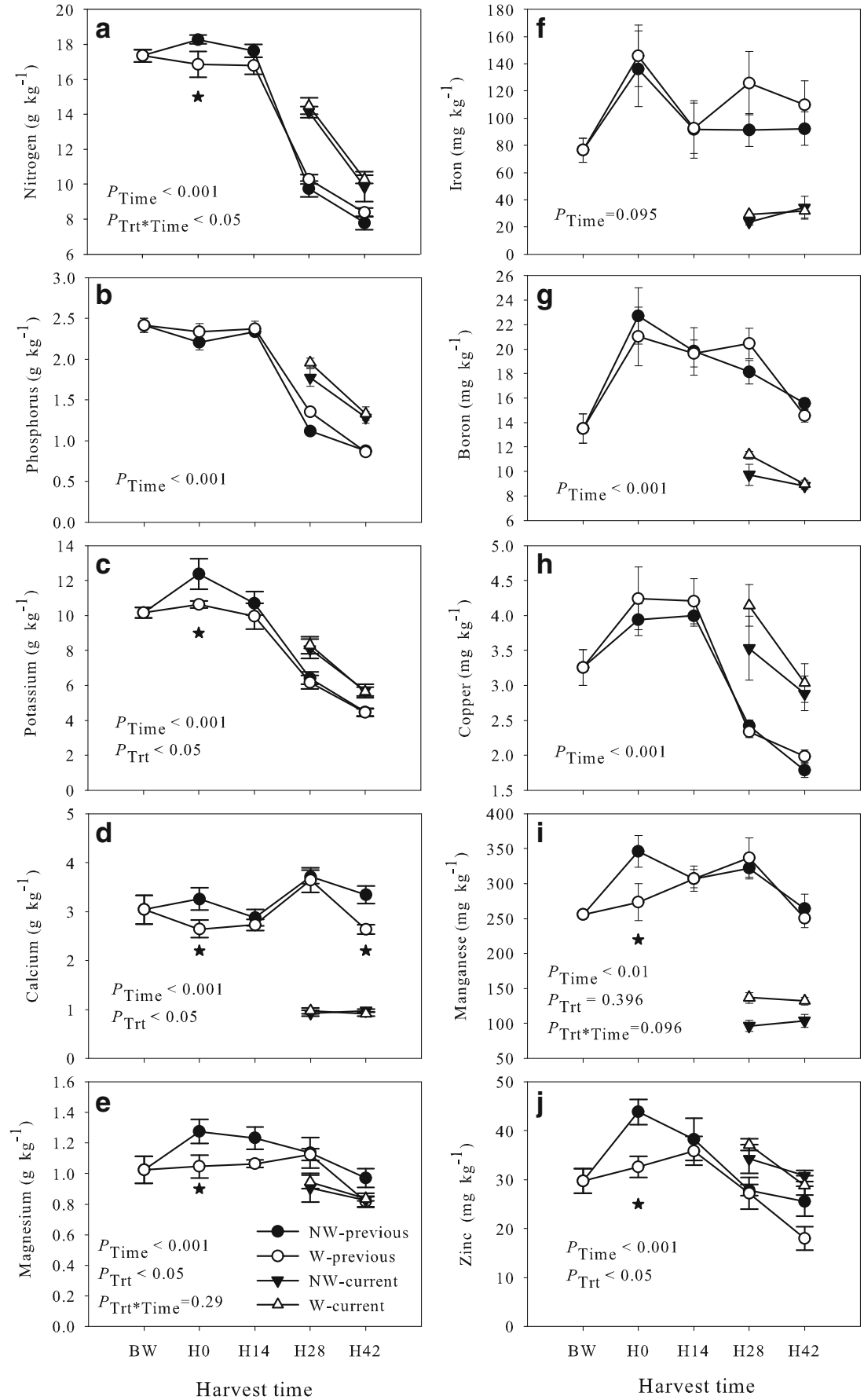

accordingly, is lower in cold than warm (Coutts and Philipson 1978; Racey 1984; Conlin and Lieffers 1993). However, despite the low oxygen consumption in cold waterlogged soils, the oxygen level may decline almost to zero within a few days or even faster after commencement of waterlogging. Roots of $P$. banksiana and $P$. mariana submerged in cold water $\left(1{ }^{\circ} \mathrm{C}\right)$ used main proportion of oxygen already within $24 \mathrm{~h}$ (Racey 1984). In the experiment with 1-year-old $P$. sitchensis and Pinus contorta, oxygen level was depleted in 6 days after waterlogging at $6{ }^{\circ} \mathrm{C}$ (Coutts and Philipson 1978). In the present study, the consequences of hypoxia were not very strong, and most of the observed differences disappeared by the end of the growth period.

The biomass of the seedlings was not affected by 1 month of waterlogging. This is consistent with the results obtained for the photochemical efficiency of the PS II $\left(F_{\mathrm{v}} / F_{\mathrm{m}}\right)$, which was not affected by the waterlogging treatment. $F_{\mathrm{v}} / F_{\mathrm{m}}$ was expected to decrease by the waterlogging treatment because it is considered as an indicator of plant stress in the photosystem 
II (Lichtenthaler and Rinderle 1988; Baker 2008). As it turned out, the photosystem II of needles of dormant spruce seedlings appeared to be resistant to waterlogging stress under the study conditions simulating winter/early spring conditions.

Accumulation of starch in needles of conifers undergoing hypoxia stress is associated with phloem transport problems in stressed plants and a reduced carbohydrate supply in the roots (Topa and Cheeseman 1992a, b; Palomäki et al. 1994; Sudachkova et al. 2009). We observed only a slight elevation of the starch concentration in the previous-year needles of $\mathrm{W}$ treatment in the initial phase of the growing season after the waterlogging, however. In agreement with this, no severe effects on root or shoot biomass were found either. Low $\mathrm{N}$ or $\mathrm{P}$ availability is observed to promote starch accumulation in conifer needles (Adams et al. 1986; Topa and Cheeseman 1992a, b; Brahim et al. 1996; Utriainen and Holopainen 2001) which might be an explanation for the increase of starch content during the growth phase.

Waterlogging resulted in a lower root volume compared with the treatment without waterlogging during the subsequent growing season. Furthermore, the proportion of dead roots in W seedlings was increased at the beginning of the growth season too, although not confirmed statistically due to high variability. Therefore, we may conclude that there was some root damage in the waterlogging treatment, but the roots quickly recovered and no other significant damage could be observed. These findings agree with post-drainage recovery of dormant Sitka spruce $(P$. sitchensis), lodgepole pine ( $P$. contorta), Scots pine and Norway spruce after waterlogging in cold (Coutts and Philipson 1978; Pelkonen 1979; Coutts and Nicoll 1990).

Root hydraulic conductivity $\left(L_{\mathrm{p}}\right)$ was not significantly affected by waterlogging. Both $L_{\mathrm{p}}$ and root hydraulic conductance $\left(K_{\mathrm{r}}\right)$ have been used to estimate the water uptake capacity of roots (Calvo-Polanco et al. 2009, 2012; Aroca et al. 2012). Although there is some controversy concerning the effects of unstirred layers on $K_{\mathrm{r}}$ measurements with HPFM (Knipfer et al. 2007), it can be safely assumed that these effects would not vary between the treatments. Hydraulic conductivity of roots has been found to decrease under flooding conditions, which has been explained by cytosolic acidification and inhibition of aquaporin activity (Kamaluddin and Zwiazek 2002; Tournaire-Roux et al. 2003). However, in eastern larch ( $L$. laricina) (Calvo-Polanco et al. 2012) and white spruce (Picea glauca) (Reece and Riha 1991), root hydraulic conductance remained unaffected by flooding, which supports our observations. Some flood-tolerant species, when exposed to flood conditions, are able to develop new adventitious roots with high $L_{\mathrm{p}}$ values (Islam et al. 2003). Although Norway spruce is also able to grow adventitious roots in response to adverse soil conditions (Puhe 2003), in this study, none were observed at the end of the next growing season.

The water potential of the needles was higher in the $\mathrm{W}$ than in the NW treatment at the end of the dormancy phase and in the early growth phase. Although this could suggest that the waterlogging had positive effects on the water relations of the needles, the positive effects were more likely to be a result of a delay in stabilisation of soil moisture after the waterlogging had ended. In the current experiment, we did not measure gas exchange of the seedlings. However, earlier studies with conifer seedlings have shown stomatal closure after waterlogging (Terazawa et al. 1992, Topa and Cheeseman 1992a). Moreover, flood-induced stomatal closure may sometimes prevent reduction in leaf water potential (Pereira and Kozlowski 1977; Kozlowski 1997). Thus, waterlogging in our study may have decreased stomatal conductance and in consequence decreased the transpiration, which could explain higher water potential in W than NW seedlings at the end of the dormancy and in the early growth phase.

The lower $R_{\mathrm{e}} / R_{\mathrm{i}}$ ratio in $\mathrm{W}$ than in NW needles is an indication of the difference in the current-carrying capacity of the apoplast and the symplast of the previous-year needles. The slightly lower $R_{\mathrm{e}}$ in W than NW needles suggests an impaired ability of cell membranes to maintain high symplastic ion concentration whereupon ions leaked into apoplastic space (Repo et al. 1994, 2000). Another possible explanation is higher apoplastic water content with less air space in $\mathrm{W}$ needles whereupon the passage of low-frequency current in the apoplastic space was facilitated and resistance decreased (Zhang et al. 1995). The elevated symplastic resistance $\left(R_{\mathrm{i}}\right)$ in W needles might be due increased viscosity due to higher starch and sugar contents but this would need further studies (cf. Gourzi et al. 2004).

The contents of $\mathrm{N}, \mathrm{K}, \mathrm{Ca}, \mathrm{Mg}, \mathrm{Mn}$ and $\mathrm{Zn}$ were higher in NW than $\mathrm{W}$ needles after 30 days waterlogging but no differences were found in the contents of $\mathrm{P}, \mathrm{Fe}, \mathrm{B}$, and $\mathrm{Cu}$. This indicates that waterlogging during the dormancy phase affected the uptake or allocation of different nutrients differently. Waterlogging is known to affect the availability of nutrients in the soil differentially (see the review by Kreuzwieser and Gessler 2010). The availability of potassium and nitrate often decreases, whereas phosphate and reduced forms of iron increase in the soil after flooding (Kreuzwieser and Gessler 2010). That is consistent with our observation that nitrogen and potassium content in the previous-year needles were slightly lower in the W than in the NW seedlings after the waterlogging. During the growth period the NW and the W seedlings did not show any differences in the nutrient contents of old or new needles. However, the contents of major macronutrients in the previous-year needles decreased in both treatments with the progress of the growth phase. We may conclude that the uptake or allocation of some nutrients was affected by waterlogging in the late winter but this did not affect the nutrient status in the growing phase following the waterlogging. Still, we cannot rule out the possibility that this effect might be significant if the seedlings would be exposed to other environmental 
stresses during the growing phase. The issue of mineral nutrition in trees subjected to winter and early spring waterlogging has not been addressed before.

In conclusion, late-winter waterlogging of dormant Norway spruce seedlings did not reduce the seedling biomass in the next growing season. Although root volume decreased and root mortality increased, waterlogging did not have a negative effect on the water uptake of the seedlings during the subsequent growth phase. Norway spruce seedlings appear to be relatively well equipped to recover from the effects of shortterm waterlogging during the dormancy phase. Still, further studies are needed to examine the waterlogging tolerance of Norway spruce during different phases of the growing period and the potentially aggravating effects of other environmental stresses occurring after waterlogging.

Acknowledgments We thank Eija Koljonen, Anita Pussinen, Urho Kettunen, Jussi Liinamo, and Jukka-Pekka Lappalainen for their technical assistance, Jaakko Heinonen for his advice on the statistical analyses, Sirkka Sutinen and Gang Zhang for their comments on the manuscript, and Pekka Hirvonen for revising the English text. The study was financed by the Academy of Finland (project 127924), the Finnish Forest Research Institute (project 3489), the Finnish network 'Doctoral Programme in Forest Sciences' and the Niemi Foundation.

\section{References}

Adams MB, Allen HL, Davey CB (1986) Accumulation of starch in roots and foliage of loblolly pine (Pinus taeda L.): Effects of season, site and fertilization. Tree Phys 2:35-46

Armstrong W, Read DJ (1972) Some observations on oxygen transport in conifer seedlings. New Phytol 71:55-62

Aroca R, Porcel R, Ruiz-Lozano JM (2012) Regulation of root water uptake under abiotic stress conditions. J Exp Bot 63:43-57

Aronen TS, Häggman HM (1994) Occurrence of lenticels in roots of Scots pine seedlings in different growth conditions. J Plant Physiol 143:325-329

Baker NR (2008) Chlorophyll fluorescence: a probe of photosynthesis in vivo. Ann Rev Plant Biol 59:89-113

Bardossy A, Caspary HJ (1990) Detection of climate change in Europe by analyzing European atmospheric circulation patterns from 1881 to 1989. Theor Appl Climatol 42:155-167

Brahim MB, Loustau D, Gaudillère JP, Saur E (1996) Effects of phosphate deficiency on photosynthesis and accumulation of starch and soluble sugars in 1-year-old seedlings of maritime pine (Pinus pinaster Ait). Ann Sci For 53:801-810

Calvo-Polanco M, Señorans J, Zwiazek JJ (2012) Role of adventitious roots in water relations of tamarack (Larix laricina) seedlings exposed to flooding. BMC Plant Biol 12:99-107

Calvo-Polanco M, Zwiazek JJ, Jones MD, MacKinnon MD (2009) Effects of $\mathrm{NaCl}$ on responses of ectomycorrhizal black spruce (Picea mariana), white spruce (Picea glauca) and jack pine (Pinus banksiana) to fluoride. Physiol Plant 135:51-61

Chow PS, Landhäusser SM (2004) A method for routine measurements of total sugar and starch content in woody plant tissues. Tree Phys 24:1129-1136

Conlin TSS, Lieffers VJ (1993) Anaerobic and aerobic $\mathrm{CO}_{2}$ efflux rates from boreal forest conifer roots at low temperatures. Can J For Res $23: 767-771$
Coutts MP, Nicoll BC (1990) Waterlogging tolerance of roots of Sitka spruce clones and of strands from Thelephora terrestris mycorrhizas. Can J For Res 20:1894-1899

Coutts MP, Philipson JJ (1978) Tolerance of tree roots to waterlogging. I. Survival of Sitka spruce and Lodgepole pine. New Phytol 80:63-69

Crawford RMM (2003) Seasonal differences in plant responses to flooding and anoxia. Can J Bot 81:1224-1246

Crawford RMM, Braendle R (1996) Oxygen deprivation stress in a changing environment. J Exp Bot 47:145-159

Glenz C, Schlaepfer R, Iorgulescu I, Kienast F (2006) Flooding tolerance of Central European tree and shrub species. Ecol Manag 235:1-13

Gourzi A, Rouane A, Alavi SM, McHugh MB, Nadi M, Roth P, Poincare $\mathrm{H}$ (2004) Body fluid characterization using a new electromagnetic biosensor: blood PIG in vitro results. In: Nowakowski A, Wtorek J, Bujnowski A, Janczulewicz A (eds.), Proc $7^{\text {th }}$ Int Conf Electr Bioimp \& $5^{\text {th }}$ Electr Imp Tomography 1: 241-244

Hansen J, Møller I (1975) Percolation of starch and soluble carbohydrates from plant tissue for quantitative determination with anthrone. Anal Biochem 68:87-94

IPCC (2007) Climate change 2007: the physical science basis. In: Solomon S, Qin D, Manning M, Chen Z, Marquis M, Averyt KB, Tignor M, Miller HL (eds) Contribution of Working Group I to the Fourth Assessment Report of the Intergovernmental Panel on Climate Change. Cambridge University Press, Cambridge, p 940

Islam A, Macdonald SE, Zwiazek JJ (2003) Responses of black spruce (Picea mariana) and tamarack (Larix laricina) to flooding and ethylene treatments. Tree Physiol 23:535-542

Jylhä K, Ruosteenoja K, Räisänen J, Venäläinen A, Tuomenvirta H, Ruokolainen L, Saku S, Seitola T (2009) The changing climate in Finland: estimates for adaptation studies. ACCLIM project report 2009. Finn Meteorol Inst Helsinki, Reports 2009: 4, 102 p. Extended abstract in English

Kamaluddin M, Zwiazek JJ (2002) Ethylene enhances water transport in hypoxic aspen (Populus tremuloides). Plant Physiol 128:962-969

Knipfer T, Das D, Steudle E (2007) During measurements of root hydraulics with pressure probes, the contribution of unstirred layers is minimized in the pressure relaxation mode: comparison with pressure clamp and high-pressure flowmeter. Plant Cell Environ 30: 845-860

Kortelainen P, Saukkonen S (1995) Organic vs minerogenic acidity in headwater streams in Finland. Water Air Soil Pollut 85:559-564

Kozlowski TT (1997) Responses of woody plants to flooding and salinity. Tree Physiol Monogr 1:1-29

Kreuzwieser J, Gessler A (2010) Global climate change and tree nutrition: influence of water availability. Tree Physiol 30:1221-1234

Kreuzwieser J, Papadopoulou E, Rennenberg H (2004) Interaction of flooding with carbon metabolism of forest trees. Plant Biol 6:299306

Lichtenthaler HK, Rinderle U (1988) The role of chlorophyll fluorescence in the detection of stress conditions in plants. Crit Rev Anal Chem 19:29-85

Palomäki V, Holopainen JK, Holopainen T (1994) Effects of drought and waterlogging on ultrastructure of Scots pine and Norway spruce needles. Trees 9:98-105

Parent C, Capelli N, Berger A, Crèvecoeur M, Dat JF (2008) An overview of plant responses to soil waterlogging. Plant Stress 2:20-27

Pelkonen E (1975) Effects on Scots pine growth of ground water adjusted to the ground surface for periods of varying length during different seasons of the year. Suo 26:25-32

Pelkonen E (1979) Seasonal flood tolerance of Scots pine and Norway spruce seedlings. Suo 30:35-42

Pereira JS, Kozlowski TT (1977) Variations among woody angiosperms in response to flooding. Physiol Plant 41:184-192

Puhe J (2003) Growth and development of the root system of Norway spruce in forest stands - a review. Ecol Manag 175:253-273 
790

A.-F. Wang et al.

Race GD (1984) Dissolved oxygen depletion by the roots of conifer seedlings during root soaking. Ont Min Nat Resour Res Notes 41:1-4 Reese CF, Rita SJ (1991) Role of root systems of eastern larch and white spruce in response to flooding. Plant Cell Environ 14:229-234

Repo T, Chang G, Ryyppö A, Rikala R (2000) Electrical impedance spectroscopy of Scots pine (Pincus sylvestris L.) shoots in relation to cold acclimation. J Exp Bot 51:2095-2107

Repo T, Zhang MIN, Ryyppö A, Vapaavuori E, Sutinen S (1994) Effects of freeze-thaw injury on parameters of distributed electrical circuits of stems and needles of Scots pine seedlings at different stages of acclimation. J Exp Bot 45:823-833

Ryyppö A, Repo T, Vapaavuori E (1998) Development of freezing tolerance in roots and shoots of Scots pine seedlings at nonfreezing temperatures. Can J For Res 28:557-567

Sallantaus T (1992) Leaching in the material balance of peatlandspreliminary results. So 43:253-258

Sarkkola S, Hökkä H, Anti E, Koivusalo H, Nieminen M (2012) Depth of water table prior to ditch network maintenance is a key factor for tree growth response. Scend J For Res 27:649-658

Scholander PF, Hammel HT, Hemmingsen EA, Bradstreet ED (1964) Hydrostatic pressure and osmotic potential in leaves of mangroves and some other plants. Proc Natl Aced Sci U S A 52:119-125

Sudachkova NE, Milyutina IL, Romanova LI (2009) Adaptive responses of Scots pine to the impact of adverse abiotic factors on the rhizosphere. Russ J Ecol 40:387-392
Terazawa K, Maruyama Y, Morikawa Y (1992) Photosynthetic and stomatal responses of Larix kaempferi seedlings to short-term waterlogging. Ecol Res 7:193-197

Top MA, Cheeseman JM (1992a) Effects of root hypoxia and a low P supply on relative growth, carbon dioxide exchange rates and carbon partitioning in Pins serotine seedlings. Phys Plant 86:136-144

Top MA, Cheeseman JM (1992b) Carbon and phosphorus partitioning in Pincus serotine seedlings growing under hypoxic and low-P conditions. Tree Phys 10:195-207

Tournaire-Roux C, Sitka M, Javot H, Gout E, Gerbeau P, Lu DT, Bligny R, Maurel C (2003) Cytosolic pH regulates root water transport during anoxic stress through gating of aquaporins. Nature 425:393-397

Tyree MT, Patiño S, Bennink J, Alexander J (1995) Dynamic measuremints of root hydraulic conductance using a high-pressure flowmeter in the laboratory and field. J Exp Bot 46:83-94

Utriainen J, Holopainen T (2001) Nitrogen availability modifies the ozone responses of Scots pine seedlings exposed in an open-field system. Tree Physio 21:1205-1213

Chang MIN, Repo T, Willison JHM, Sutinen S (1995) Electrical imperance analysis in plant tissues: On the biological meaning of ColeCole $\alpha$ in Scots pine needles. Eur Biophys J 24:99-106

Chang MIN, Willison JHM, Cox MA, Hall SA (1993) Measurement of heat injury in plant tissue by electrical impedance analysis. Can J Bot 71:1605-1611

Springer

INA

SCIENCE \& IMPACT 